\title{
Moodle as Builder of Motivation and Autonomy in English Courses
}

\author{
Erdal Ayan \\ Hitit University, Çorum, Turkey \\ Email: erdal_ayan@yahoo.com
}

Received 5 January 2015; accepted 23 January 2015; published 27 January 2015

Copyright @ 2015 by author and Scientific Research Publishing Inc.

This work is licensed under the Creative Commons Attribution International License (CC BY). http://creativecommons.org/licenses/by/4.0/

(c) (i) Open Access

\begin{abstract}
Moodle is one of the mostly used open source learning management systems. It may create an encouraging, informative and always renewable language education environment. It is both motivating and autonomy building in particularly English language courses. In this paper, focus of the research is to survey on Moodle's position to motivate and create autonomous e-learning in English language courses. Distinctive features of this study were that language learners who were participants of the study did not experience English preparatory class at university level and never used a particular learning management system (LMS) to learn English before. They had weekly four hours of English language classes in each term for four years of their bachelor education. The students used Moodle to learn and improve their English with asynchronous applications as an extension to face-to-face sessions of the courses. At the end of almost four months of study, averages of their exam scores and a satisfaction questionnaire were used to evaluate the effectiveness of Moodle on students' motivations and autonomous learning. As a consequence of the study, it was observed that Moodle considerably contributed to the levels of their motivation and autonomy to improve their English language skills.
\end{abstract}

\section{Keywords}

Moodle, Motivation, Autonomy, e-Motivation, e-Learning

\section{Introduction}

Nowadays students are very curious about Internet and computer technologies, and almost all of the students have got a face-book account. That is a very strong potential, since the students love sharing, finding information about other people and spending a huge amount of time on Internet. If the time spent on face-book or any other on-line social media is regarded, undoubtedly it seems that most of the students tend to use computer and 
Internet for extracurricular activities. They mostly share news, pictures with smiling faces, videos, etc. about themselves on social media sites like face-book, you-tube, etc. They can easily keep themselves using computerized technologies for hours and even days, and they are certainly doing this autonomously and even independently in a highly motivated manner. On the other hand, sometimes many of them just waste their time for nothing in terms of research and education but only for the sake of having fun. In addition, interestingly, there are actually many students who are face-book experts but can not use any other web-sites, basic software programs such as word processor or excel programs at schools at university levels in Turkey. And it is a challenging question if any LMS can compete with face-book and other social media tools to re-direct learners' attention to real learning processes. This question obviously and mostly has responses depending on the needs of the students as well as a good guiding curriculum with a virtual learning environment (VLE).

Another fact is that English has already changed into a lingua franca in almost all fields of study. However, it is still a challenging question how to learn and teach English in a very short time in especially those countries where English is not a second language. Therefore, facilities such as Internet access, computer rooms, curriculum, library support as well as well trained language trainer are determining quality of English language education at any institution. These facilities are actually required and encouraging bases for both the teachers and students to diversify the learning environments. In this regard, many institutions, publishers, organizations and foundations which are working on language education have recently tended to have particular learning management systems or on-line contents. For example, Higher Education Council of Turkey started a multimedia classrooms project including a web-portal ${ }^{1}$ for distance language education and invested on an LMS called NetLanguages $^{2}$ for all students registered at Turkish universities. Oxford University Press and Cambridge University Press, which are two leading publishers, have their own LMS $^{3}$ from famous media/press such as Voice of America, The Guardian, and $B B C$ publish many materials of language teaching and learning for free of charge. Moreover, BBC Learn English and British Council have got particular web-sites to support language education, and publish lots of practices and packages on various skills changing from pod-casts, specific videos, grammar \& vocabulary activities. Admittedly, these resources can easily be used for purpose of "blended learning", which is an education program in a great request and easily integrable in English courses (Staker \& Horn, 2012).

Web-based applications which encourage students to learn a language have turned into real and basic needs for everyone when compared to the traditional methods and materials used in the recent past. Recently, Moodle as an open source virtual learning environment has been broadly used for that purpose by many scholars, teachers and institutions from different fields of sciences all over the world. According to the statistics from Moodle.org currently there have been 64,232 registered Moodle sites, and 418 of those are the sites used in Turkey ${ }^{4}$. However, there are not certain data about the percentage of those Moodle sites which are particularly used for English language education in Turkey. Additionally, there are plenty of academic releases on Moodle's advantages on different fields of research. There are many other academic studies on "e-learning", "e-motivation" and autonomous learning in the literature, as well (Borg \& Al-Busaidi, 2011; Chourishi, Chanchal, Chaurasia, \& Soni, 2011; Mayer, 2013; Price \& Kadi-Hanifi, 2011; Razak \& See, 2010). It seems to me that Moodle’s position as a motivation and autonomy builder in particularly English language courses needs to be more focused in the literature of English teaching as a foreign or second language. In accordance with that, this study aims to contribute Moodle's effectiveness on motivation and autonomy in e-learning in English language education.

Motivation and autonomy are two concepts associated with learning and noting progress in language. They mostly go hand in hand; that is, they closely affect the quantity, understandability and clarity of outputs by the learners. Therefore, initially, relationships between motivation and autonomy in language education are to be clarified. Then the process of research will be narrated to transfer specific steps from installation to creating contents and catching the students' attentions. Lastly, detailed data analyses and discussion will be followed.

\section{Literature Review}

\subsection{Motivation and Autonomy in e-Learning}

Various definitions for both terms, motivation and autonomy, are available in the literature of language educa-

\footnotetext{
${ }^{1}$ For further information see http://ide.yok.gov.tr

${ }^{2}$ For further information see https://dilegitim.yok.gov.tr/yok/welcome.php

${ }^{3}$ For further information see https://www.oxfordenglishtesting.com/ \& http://www.cambridgelms.org/p/splash

${ }^{4}$ For further information see https://moodle.org/stats/
} 
tion and motivation theories (Borg \& Al-Busaidi, 2011; Chateau \& Zumbihl, 2012; Dickinson, 1995; Peng \& Woodrow, 2010; Price \& Kadi-Hanifi, 2011) and there are even long lasting attempts to define and describe intrinsic and extrinsic motivations and their effects on success (Dickinson, 1995). Motivation has been attributed to "individual differences" and autonomy is characterized by those individual differences to express and reveal identities in connection with specific needs and interests (Ushioda, 2011: p. 12). It is also similar to the origin of both terms even though motivation is a common term in psychology and autonomy in political sciences. Ushioda (2011) notes that motivation as a theory has been originated in "positivist cognitive paradigm" and described it as "development of mental processes, learning outcomes and behaviors" whereas autonomy has been improved in "constructivist paradigm" and it means "specific context of practice, needs and concerns of particular learners" (11-2).

Mostly, the process of face-to-face education is made up of very short moments when both the students and teachers have not any problems in communication and educational skills (Gordon, 1975). These moments are the times which both students and teachers have utmost motivation, which is sometimes limited to convey very little information or feedback. As Moskovsky et al. (2013) mention in their recent research on teacher's effect on motivation, "teacher behavior is responsible for enhanced motivation" in face-to-face language education (58). Motivation is always under strict control of the teacher through activities, practices, language games, etc. Furthermore feedback by the teacher is mostly problematic in terms of potentially causing a negative face during classroom teaching. In contrast, any feedback from a colleague may not be so threatening for many students since the feedback does never dictate anything and tend to be discouraging. It may certainly lead to discussions but it may also trigger critical thinking mechanisms in students' minds.

Sometimes autonomous learning may be regarded as an independent learning, but it is actually not. To put it simply, as Jones (2011) mentions that the term, autonomous learning, refers to guided learning which does not allows students to be "alone" but let them decide by themselves, choose between certain paths and improve their own ways of learning. This type of autonomy improves required collaboration and personalized or self-learning among classmates rather than a competition. In this regard, the definitions for autonomy by Holec (1981: 3) and Benson (2001: 2), which are referring to the notion of "responsibility" of self-learning seem more informative (as cited in Chateau \& Zumbihl, 2012; Dickinson, 1995).

\subsection{Motivation and Autonomy Revisited in Different Conditions}

The conditions outside and inside the classroom are of differences in the level of motivation and autonomy. Students may not be so willing to speak inside the classrooms because of changing reasons, but they may tend to represent their natural identities and interests outside the classroom. Gordon (1975) has provided favorable examples for such conditions, which clear-cut changes take place in attitudes of the learners. For example, one of the students said "When I got to the school, I withdraw into myself. I do whatever they (teachers) want, I read exam sheets and try not to attract any attention. But when the school, I turn in on myself again ${ }^{5}$.” (Gordon, 1975: 245). In connection with that, Ushioda (2011) describes "transportable identities", which simply means that students may connect and bridge their worlds, roles, behaviors and relationships inside and outside the classroom. In the eastern cultures the roles and positions of the teachers and students as well as the scope of teacher-student interactions are already pre-determined, and the teachers are the only authorities in the classrooms (Peng \& Woodrow, 2010). Therefore transportable identities are not always so easy for students to show up especially in certain cultures.

There are noteworthy studies on e-motivation and autonomy in the literature (Jones, 2011; Price \& KadiHanifi, 2011). In the e-learning processes the conditions determining the level of motivation and autonomy are not always the same, since the learners are in interaction with a content uploaded in computer and Internet environments. Park et al. (2013) inform that confusion and the design of learning materials may have benefits on cognitive processes motivation of the learners. Even asynchronous and synchronous tools and activities may affect the level of motivation depending on "individual differences" between learners (Giesbers, Rienties, Tempelaar, \& Gijselaers, 2014). The learners decide their own position, time and place that they are going to do the tasks, that is, the atmosphere and environment are mostly different from those which are presented in the classroom teaching. The level of motivation is mostly depend on the content of the on-line course which is addressing to students' interests. The content also defines the autonomy as much as independence. On the other hand,

\footnotetext{
${ }^{5}$ My own translation from Turkish to English.
} 
during classroom teaching students potentially tend to get stressed because of continuous feedback by the teacher. In this sense, VLE provide an environment encouraging freedom of expression in accordance with their needs and interests. Students mostly collaborate with each other inside the classrooms but they may create a global collaboration by means of the VLE.

\subsection{The Present Study and Research Questions}

One of the most challenging problems, which many teachers of English language suffer from inside and outside the classrooms, is how to motivate students and create an autonomous learning in especially the countries where English is of a foreign language status. Students mostly do not have an encouraging and input-rich environment outside their classrooms and sometimes even during face-to-face teaching. Providing enough motivating materials and keeping the students always on work of learning process mostly only burden language instructors and experts at material offices at many state and private universities. Even though a lot of effort, money, energy and time have been spent on teaching English in particularly classroom environments so far, the teacher-student interaction or contact works for a certain extend in certain classroom sessions, and many students are just left alone outside the classrooms after completing the courses.

Furthermore, some threatening conditions such as negative face because of negative and continuous feedback by the teacher, other students' faces against some certain students, noisy atmosphere of classrooms due to crowded classes, problem behaviors or habits of some groups of students, etc. are always present in face-to-face teaching in classrooms. Duration of class-time (55 min. at most) defines and limits role of the teacher as well as the activities which are planned to be completed in course time. On the other hand, non-homogeneous classrooms in terms of students' knowledge of English has been a serious challenge for language teachers. All these factors might play a negative role on the level of motivation and anxiety as well as communication engagements of the students.

Same or similar problems were also described in the language learning environment of the school where the study was conducted. Accordingly, to cope with these problems and to create an extension to classroom teaching Moodle (2.0) was installed in the early February 2012. Just after installation, Moodle site was named Hitit.Moodle in order to create a sense of institutional belonging on students ${ }^{6}$. The study was conducted in the Faculty of Science and Arts. The questions that encouraged me to install Hitit.Moodle and set up the study were as follows: a) "How can the learners be motivated to use English outside the classroom?" b) "How can the teacher help them be as autonomous as possible to learn English?” c) "What type content can contribute to their own interests and fields of study in English?" d) "To what extend could Moodle site play a role on motivation and autonomy?” In this sense, the aim of the study was to help students use and expose English more outside the course and school environment. The study was to make them familiarize with computerized English learning materials. The study also aimed at promoting their e-motivations and autonomy to learn English. Moodle was not totally used as a distance education tool but as a supporting environment to face-to-face language education in this study.

\section{Methodology}

\subsection{Participants}

The study was conducted at the department of Chemistry at Hitit University located in Turkey. The students, who were registered at the department of Chemistry, used Hitit.Moodle for around four months. The number of the most active participants was 73 and the number of questionnaire participants was 78 . As mentioned in the department's curriculum, the enrolled students were responsible for weekly four hours of English courses in each semester from the first year until the end of the fourth year. Second, third and fourth year students were assigned to use Hitit.Moodle, which made three classes having at least thirty-five students on average. The classrooms were not homogeneous in terms of the levels of language knowledge even though most students had already taken English courses in primary, middle and high schools in Turkey. Also they had never used on-line tools or LMSs such as Moodle to learn and practice English before. The faculty did not have any kind of LMS for students, either.

\footnotetext{
${ }^{6}$ See www.moodle.hitit.edu.tr
} 


\subsection{Instruments}

Just after the students registered at the site and the on-line courses over Hitit.Moodle, they could see weeklyplanned contents. The students were charged weekly packages which were mostly parallel but not totally the same to topics represented in their course books during face-to-face sessions. These packages were including different activities based on the skills changing from integrated and segregated practices. These practices were mostly designed according to task-based methodology. That is, the activities such as basic grammar practice sheets, listening and writing, reading and writing, watching and writing, were provided. Weekly writing assignments were only given to intermediate and upper-intermediate students. Deadlines were intentionally determined for these assignments and some certain practices such as quizzes and on-line lessons. The weekly assignments were checked by the instructor and on-line feedback dealing with syntax, grammar, vocabulary selection, etc. was given to the students each week. The contents on the system were used to collect writing samples and determine their activities as well as performance on the web-site. Grading and assessment system of the university was employed to define if there were any difference between the total grades in the fall and spring terms. At the end of the spring term, a satisfaction questionnaire was designed to get participants' tendency and ideas towards using Hitit.Moodle.

\subsection{Instructional Design}

At the beginning of the spring term, students were informed that Hitit.Moodle was going to be used to help them improve their English language skills. In addition to their course books, (pre-intermediate and intermediate levels) for the second and third year students and (upper-intermediate level) for the fourth year students were followed. The study is based on application of out-of-class activities which were particularly asynchronous activities such as, writing assignments, listening activities, forums, quizzes, sound/video recordings, and extra grammar packages/sheets over Hitit.Moodle. Various asynchronous activities were intentionally given because it was believed that different types of practices had notably important roles to play on the student motivation and autonomous learning. Traditional multiple choice question formats were not mostly preferred, most of the time authentic information and activity based questions were chosen, instead. These activities were assigned for the students who took the course almost four months in the spring term of 2012 academic year. The students were also supported by useful links to get on-line help on grammar and vocabulary. In this sense, "blended” language teaching methodology was largely used in the study (Hubackova, Semradova, \& Klimova, 2011).

\subsection{Data Collection}

Especially sources which are free of charge and open access mostly from the press/media, you-tube, and book publishers were used to create these activities and practices. Remote Rich Site Summaries (RSS) particularly on science and chemistry from Scientific American and BBC Science and Environment, BBC Documentary Archive and a daily vocabulary block from Dictionary.com were added in to the course contents (See Appendix 1). Average grades from the fall and spring terms were compared. At the end of the fourth month, the satisfaction questionnaire (See Appendix 2) including seven multiple choice questions and an open-ended question on the users' ideas about Hitit.Moodle was conducted. The factors such as age, gender and personality were not regarded in the questionnaire. The students were asked not to write their names on the questionnaire sheets and were allowed to write their comments in Turkish for the open-ended question. The data taken from the questionnaire were analyzed both in .excel and PSPP which is free and alternative software for statistical analyses for well-known SPSS.

\section{Findings}

\subsection{Challenges}

As Chateau \& Zumbihl (2012) have noted in their article, the quality relationship and dialogue between the teacher and learners may significantly change the attitudes and even prejudices of the learners which "block their autonomization process" (33). Therefore, Hitit.Moodle has proved that it may set up such a good relationship and dialogue as well as an encouraging alternative and effective environment as an LMS for students to be as autonomous as possible. On the other hand, at the end of the study, some certain challenges dealing with in- 
stallation, using and managing Hitit.Moodle system were noticed. These challenges were divided into three subcategories. These are namely teacher-focused, institution-focused and learner-focused challenges that I sum up below. It is worth to note that these challenges caused reconsideration of whole content and system and to take some decisions to manage it.

\subsection{Teacher-Oriented Challenges}

\section{a) Time Management}

There was not a ready-made contents for on-line support inside Hitit.Moodle. Therefore, time was the key factor for creating supporting contents and management of Hitit.Moodle system. It was not sometimes that easy to find out and improve parallel activities with the course book without any previous preparation. Workload of improving appropriate on-line materials mostly took a lot of time. Some of the assignments especially weekly writing assignments were of deadlines and the students should complete the tasks within five days. Otherwise the task would be turned into inactive and the student could not see and access the task. Sometimes the deadlines were extended especially when the students asked because they mostly complained about time limits of the system. The deadlines and time limits were intentionally determined because these were the alerters for students' responsibilities, kind of evaluation of their performances and as well as preventive mechanisms for cheating. The deadlines were also implemented to provide the instructor take his time and write and send the feedback.

\section{b) System Management}

At the beginning of the term when Hitit.Moodle was installed on university's main server, on-line registration over e-mail based self-registration and confirmation was activated and university's mail server was determined as simple mail transfer protocol (SMTP) host. But it was found that university's mail server did not work efficiently some time later perhaps because of intense e-mail trafficking. Therefore, e-mail based self-registration was deactivated and many students were registered at the site manually until the problem in the university's mail server was resolved. However, the problem in university's mail server could not be solved on time, so a private mail server's SMTP was used in order to let the students register by themselves. During e-mail based self-registration, it was realized that keeping the registration system active may be a threat to main system since many people from all around the world who are very curious but who are not actually registered students had an account at the site. In order to avoid any threat from those people, duration of the registration was limited to a week and enrollment keys were defined to enroll at the courses.

\subsection{Institution-Oriented Challenges}

\section{Access to Internet, Library Facilities and Grading System}

It was seen that the students tended to use Hitit.Moodle mostly from their homes or dormitories because there were not Internet access points and wireless system in the faculty building. Central library did not have enough numbers of computers as well as enough room for individual learning even though the wireless system was present inside it. All quiz results and some other activities were objectively graded since many of the students were accustomed to see any activity as a work that should be graded. However, it was determined that the general grading system of the school did not allow extra grading for quizzes and other evaluations. In other words, only midterm results and final grades could be regarded in the grading system; therefore, the quiz results and other grades from on-line activities could not be evaluated separately but added to their midterms and finals. Actually, it was a disadvantage because the students were aware of this condition, which did not allow to put emphasis on the use of Hitit.Moodle and created a little unwillingness among the students to log on to the site in the very first days of the term.

\subsection{Learner-Oriented Challenges}

\section{a) Student Profiles and Language Knowledge}

Student profiles were not all the same in terms of their preparedness and language knowledge. For example, some students, who are especially pre-intermediate levels, did not have enough knowledge of vocabulary even though they tended to be very active and willing in outclass activities such as video recording. Therefore nonhomogeneous classes were obviously present during at the time of the research. This was mostly a disadvantage for the instructor since it was always not so simple to prepare appropriate on-line materials addressing to any 
student from any level of language knowledge. And this condition caused huge time consuming trial and error processes. However, it was a great advantage for those students with low proficiency of English because they obviously found enough opportunities to use many on-line materials and improve their language skills outside the classroom.

\section{b) Student Tendencies}

At first, students tended to do the practices for nothing but for only grades. Initially, this seemed like a strange and insignificant demand but just after starting to the study, it was observed that most of the students did not log in to the site for almost two week's time after registering at the site. This demand was very usual for them because of reward-focused education system which has mostly had only exam-based assessment and evaluation procedure in Turkey. Then it was announced that their participations on the site were going to be graded according to the number of the practices and exercises that they would successfully complete, despite that fact that there was not a grading system regarding their active participations at the university's evaluation, testing and grading system. This was the only solution to encourage them to use the system, which is demanding and depending on their spending enough effort and time. However, some time later, it was seen that the students began logging into the site, presumably they realized that the reward of grade would come up with better final results and they could learn English as long as they did the activities provided. In addition, as a result of video recording assignments, the students attempted to use English outside the classrooms, which created self-confidence and higher motivation to independent speaking.

\section{c) Plagiarism}

It was observed that some students tended to copy and paste text from any forums and websites for their weekly writing assignments even though they were warned about plagiarism at the beginning of the term. When this tendency was noticed, some certain precautions were taken accordingly. Suspicious texts were checked by means of $U_{r k u n d}{ }^{7}$ service for plagiarism (See Appendix 4). As a result of Urkund process, the plagiarized texts were not graded and this process was declared to the students but no legal punishment was noted on detriment of the students. And some time after it was found that plagiarism was precluded and students attempted to write their text by themselves.

\subsection{Comparison of the Grades}

At the end of the research process, the results from their exams of the students would be correlating and increasing with their active participations in Hitit.Moodle. Comparison of results gotten from end of year exam averages was shown for three classes in Table 1. From the averages, it has been observed that pre-intermediate and upper-intermediate classes have noted higher averages in the spring term of the year when compared to fall term of the same year. Interestingly, intermediate class noted lower averages when compared to other classes as well as the averages of the fall term of the same year. It has been supposed that the performances, motivation on the exam dates, language level of the students and other determining factors such as efficient use of the site, difficulty level of the exam questions have played an important role in this result. Obviously, the average scores of the intermediate students did not correlate with the number of active users of the site. However, despite lower grades from the exams (midterm, quiz and final exam), it was observed that more than half of the intermediate students were still active users of the site and did not stop using the materials and doing on-line practices. Therefore, in contrast to common agreement for close relationship between success and motivation (Dickinson, 1995; Moskovsky et al., 2013), it seemed to me that the intermediate students behaved in a different way and managed to keep their motivations in certain levels.

\subsection{Analyses of the Questionnaire Results}

Seventy-eight students participated in the questionnaire. The data from the questionnaire showed that 38.46 percent of the participants used Hitit.Moodle once a week while 25.64 percent never used it (See Table 2). The reasons for this condition can be the problem of instant access to the Internet since there was not enough wired access points and a wireless facility in the faculty building. Most of the students tried to use the system either from the central library or from their homes and dormitories, which sometimes caused waste of time and delays in handing assignments.

\footnotetext{
${ }^{7}$ Urkund is a web site which is commonly used for checking written documents for any kind of plagiarism. For further information see http://www.urkund.com/en/
} 
Table 1. Averages of exams and the number of the active users.

\begin{tabular}{cccc}
\hline Year \& Term & 2011-2012 Fall Term Averages & 2011-2012 Spring Term Averages & Number of Active Users \\
\hline Pre-intermediate & 52.815 & 57.819 & 17 \\
Intermediate & 63.680 & 52.925 & 21 \\
Upper-intermediate & 67.363 & 69.212 & 35 \\
\hline
\end{tabular}

Table 2. Statistics for frequency of usage.

\begin{tabular}{|c|c|c|c|c|c|}
\hline \multicolumn{6}{|c|}{ Frequency_of_Usage } \\
\hline Value Label & Value & Frequency & Percent & Valid Percent & Cum Percent \\
\hline Once a week & 1.00 & 30 & 38.46 & 38.46 & 38.46 \\
\hline Twice a week & 2.00 & 14 & 17.95 & 17.95 & 56.41 \\
\hline Three times a week & 3.00 & 14 & 17.95 & 17.95 & 74.36 \\
\hline Never & 4.00 & 20 & 25.64 & 25.64 & 100.00 \\
\hline \multicolumn{2}{|c|}{ Total } & 78 & 100.0 & 100.0 & \\
\hline
\end{tabular}

Default interface of Moodle was used throughout the research and no other specific interface types were enjoyed in the main site and sub-sites of the courses rather than RSS feeds, comment blocks and forums for students (See Appendix 1). However, some students found it difficult to use Hitit.Moodle's default interface, which presumably caused little bit anxiety between students. More than half of the students mentioned they had "sometimes" difficulties in finding their ways in the site (See Table 3). It may be argued that this condition is sometimes a serious reason affecting the level of their motivation while they were attempting to do the exercises.

In conjunction with difficulties in using Hitit.Moodle's site, the statistics about teacher support to guide students (see Table 4) showed that more guidance was needed for students since it certainly took some significant time for them to get used the interface of the site. Even on-line office hours should have been present in certain hours of a day because only normal two-hours-long office hours and sometimes some help were provided during very little durations just before face-to-face courses, therefore, this was clearly not enough for many students.

Of those who participated in the questionnaire, some certain number of students marked more than one practice types. In the light of the statistics in Tables 5-7, most students enjoyed grammar packages, listening activities, forums and weekly essay writings created on Hitit.Moodle. Accordingly, one of the participants commented that "the content was good in terms of practicing writing and listening skills". Another student wrote that "I like(d) weekly writing assignments and getting feedback most.” From especially writing assignments (See Appendix 3) and discussions in the forums it was very promising to see that the participants created their own way of e-motivated and autonomous learning styles. Notably, this was perhaps because the students did not have an English using environment to listen, write and communicate intentionally and consciously in English. Also, the tendency to use grammar packages referred to that common traditional student perspective to use grammar for initial learning was still present among students.

Apparently, most of the students noted that Hitit.Moodle helped a lot in learning new issues. It shows that students are mostly satisfied with the content of the on-line materials. However, there seems an important percentage of participants who did not want to comment and who still have biases that it did not help that much (Table 8). Additionally, more than half of the participants agreed that the content provided over Hitit.Moodle helped them revise what they learned in the face-to-face sessions of the course (Table 9). Some important proportion of the students obviously thought the content did not revise course materials since the same topics were not repeated all the time by Hitit.Moodle. But mostly the contents focused on certain blended skills, such as reading, listening, speaking, writing and even thinking.

All of the participants did not seem so willing to use any type of Moodle applications in their future studies for their potential students even though there was a significant group of students who want to go further and use it in the future (Table 10). The statistics proved that Hitit.Moodle provided an inspiration and even motivation to a certain extend over their willingness to use a similar Moodle site in the future.

As for the open-ended questions, the participants provided their comments about Hitit. Moodle under two categories; namely, "like” and "dislike” in the open-ended question. In the "like” part many participants came up 
Table 3. Statistics for level of difficulty of the site.

\begin{tabular}{cccccc}
\hline & \multicolumn{5}{c}{ Difficulty_in_Using } \\
\hline Value Label & Value & Frequency & Percent & Valid Percent & Cum Percent \\
\hline No Comment & 0.00 & 2 & 2.56 & 2.56 & 2.56 \\
Always & 1.00 & 10 & 12.82 & 12.82 & 15.38 \\
Frequently & 2.00 & 5 & 6.41 & 6.41 & 21.79 \\
Sometimes & 3.00 & 44 & 56.41 & 56.41 & 78.21 \\
Never & 4.00 & 17 & 21.79 & 21.79 & 100.00 \\
& Total & & 78 & 100.0 & 100.0 \\
\hline
\end{tabular}

Table 4. Statistics for instructor help.

\begin{tabular}{|c|c|c|c|c|c|}
\hline \multicolumn{6}{|c|}{ Instructor_Help } \\
\hline Value Label & Value & Frequency & Percent & Valid Percent & Cum Percent \\
\hline No Comment & 0.00 & 5 & 6.41 & 6.41 & 6.41 \\
\hline Always & 1.00 & 20 & 25.64 & 25.64 & 32.05 \\
\hline Frequently & 2.00 & 9 & 11.54 & 11.54 & 43.59 \\
\hline Sometimes & 3.00 & 28 & 35.90 & 35.90 & 79.49 \\
\hline Never & 4.00 & 16 & 20.51 & 20.51 & 100.00 \\
\hline \multicolumn{2}{|c|}{ Total } & 78 & 100.0 & 100.0 & \\
\hline
\end{tabular}

Table 5. Statistics for usage of different types of the activities.

\begin{tabular}{cccc}
\hline More than one & More than two & More than three & More than four \\
\hline 28 & 11 & 7 & 4 \\
\hline
\end{tabular}

Table 6. Statistics for mostly used activities.

\begin{tabular}{cccccc}
\hline & \multicolumn{5}{c}{ Mostly_Used_Types } \\
\hline Value Label & Value & Frequency & Percent & Valid Percent & Cum Percent \\
\hline Listening Activities & 2.00 & 7 & 25.00 & 25.00 & 25.00 \\
Grammar Packages & 3.00 & 10 & 35.71 & 35.71 & 60.71 \\
Informative Web Links & 4.00 & 1 & 3.57 & 3.57 & 64.29 \\
Short Videos & 5.00 & 7 & 25.00 & 25.00 & 89.29 \\
Weekly Essay Writing & 6.00 & 3 & 10.71 & 10.71 & 100.0 \\
Total & & 28 & 100.0 & 100.0 & \\
\hline
\end{tabular}

Table 7. Statistics for mostly used activities.

\begin{tabular}{|c|c|c|c|c|c|}
\hline \multicolumn{6}{|c|}{ Mostly_Used_Types } \\
\hline Value Label & Value & Frequency & Percent & Valid Percent & Cum Percent \\
\hline No Comment & 0.00 & 15 & 19.23 & 19.23 & 19.23 \\
\hline Forums & 1.00 & 16 & 20.51 & 20.51 & 39.74 \\
\hline Listening Activities & 2.00 & 19 & 24.36 & 24.36 & 64.10 \\
\hline Grammar Packages & 3.00 & 16 & 20.51 & 20.51 & 84.62 \\
\hline Informative Web Links & 4.00 & 1 & 1.28 & 1.28 & 85.90 \\
\hline Short Videos & 5.00 & 6 & 7.69 & 7.69 & 93.59 \\
\hline Weekly Essay Writing & 6.00 & 5 & 6.41 & 6.41 & 100.0 \\
\hline Total & & 78 & 100.0 & 100.0 & \\
\hline
\end{tabular}


Table 8. Statistics for the level of satisfaction.

\begin{tabular}{cccccc}
\hline & \multicolumn{5}{c}{ Learn_New_Things } \\
\hline Value Label & Value & Frequency & Percent & Valid Percent & Cum Percent \\
\hline No Comment & 0.00 & 6 & 7.69 & 7.69 & 7.69 \\
Hepls a lot & 1.00 & 46 & 58.97 & 58.97 & 66.67 \\
It does not help & 2.00 & 26 & 33.33 & 33.33 & 100.00 \\
& & & 78 & 100.0 & 100.0 \\
\hline
\end{tabular}

Table 9. Statistics for the level of satisfaction.

\begin{tabular}{ccccccc}
\hline & \multicolumn{5}{c}{ Revising_lectures } \\
\hline Value Label & Value & Frequency & Percent & Valid Percent & Cum Percent \\
\hline No Comment & 0.00 & 6 & 7.69 & 7.69 & 7.69 \\
Yes & 1.00 & 41 & 52.56 & 52.56 & 60.26 \\
No & 2.00 & 21 & 39.74 & 39.74 & 100.00 \\
& & 78 & 100.0 & 100.0 & \\
\hline
\end{tabular}

Table 10. Statistics for the future motivation to use moodle.

\begin{tabular}{cccccc}
\hline & \multicolumn{4}{c}{ Revising_lectures } \\
\hline Value Label & Value & Frequency & Percent & Valid Percent & Cum Percent \\
\hline No Comment & 0.00 & 12 & 15.38 & 15.38 & 60.26 \\
Yes & 1.00 & 47 & 60.26 & 24.36 & 15.38 \\
No & 2.00 & 19 & 78 & 100.0 & 100.0 \\
& Total & & & & \\
\hline
\end{tabular}

with positive and promising responses. Not all but some of the comments from students were as follows:

Student-1

"I improved my knowledge of vocabulary. Sometimes the system challenged us. But it was enjoying. I think I enjoyed and improved myself. It was something different...”.

Student-2

"I think I improved my English in terms of both listening and writing."

In the "dislike" part, most of the participants complained about the deadline procedure for some practices like quizzes, on-line lessons and weekly writing assignments. Some other group of students mentioned that they did not have always Internet access to complete the tasks on-line and other courses put another burden on the students' motivations.

Student-1

"Actually it (Hitit.Moodle) is a well-prepared program. I could not use it properly because of the difficulties in accessing the Internet and it was very bad to have time limitations. That is, the deadline beginning on Monday and ending on Friday was very bad since because of the intensity of other courses I could not focus.”

Student-2

"I could not spend enough time in particularly busy week because the duration to complete some of the tasks was limited to a week."

The student comments indicated that they found enough opportunity to use Hitit.Moodle and the system helped them motivate themselves to become autonomous learners. Especially, the comments on "dislikes" showed that the students mostly suffered from the deadlines, limited Internet access, other courses and even graded quizzes. All these results proved that they spent effort to use the system and, more importantly, came up with certain challenges which closely affected the management of the system and inspired new ideas for future course designs. Moreover, intense use of forums by means of personal comments and use of videos as well as external links to support their ideas proved that the participants internalized and individualized their learning styles by improving their own paths to learn English. 


\section{Discussion}

Gao \& Lamb (2011) inform that there is an important emphasis on the interrelation between motivation, autonomy and identity of the learners. Dickinson (1995) also writes that there is an important link between autonomy and motivation, which enhances and increases motivation. However, as far as I have learned from the results of my study, the close relationship between those three notions begins with the interest and willingness of the learners, which generate elements and particular behaviors of the identity. Therefore, the process of any type of learning begins with interest and willingness, and continues with motivation and autonomy. Some students love football and some others like listening to and watching political discussions. On the other hand many students enjoy audio-visual and on-line materials and many others are willing to have traditional hard-pack exercises on sheets. Perhaps, to define and describe the types of interests that target students may potentially have inside and outside the class-time is going to help a lot to motivate students individually and let them have autonomy in learning. Furthermore, it will help create students' interests centered course contents and make natural collaborations among the students.

Additionally, it has been observed that the students from young generations are mostly in a position to share their ideas generated by their interests by means of pictures, videos, short texts and messages. As Chapelle (2007) mentions, "learner interests and linguistic needs" go hand in hand with learning styles which have a significant effect on autonomy and/but I think together with linguistic needs, any daily and survival needs in terms of use of foreign language should also be regarded (79). In this regard, Moodle site may be designed just as forums and be center of these sharing processes and make others to see these ideas simultaneously and allow them to make comments again, not necessarily like in face-book but perhaps in an educational manner like in many other social media sites. This will potentially create a circulation of learning, that is to say, learning new issues on any topic will come up with new interests and again motivation and autonomy to learn over and over.

Dickinson (1995) notes that autonomy is "an attitude towards learning and a capacity for independent learning" but I argue that any type of motivation and autonomy are two fundamental steps for independent language learning and even improving scientific research skills in English (166). Only when students are supported and encouraged by means of practices and exercises such as discussions, participatory and collaborative activities which are particularly addressing to their interests and needs, their motivations are going to hit the top. In return, this will also promote their understanding to learn how to learn by themselves. Regarding the research questions, it was seen that learners could be motivated to learn English outside the classroom through intensive use of Hitit.Moodle. The learners were as autonomous as possible while spending time with completing assignments and doing exercises given. The contents dealing with science and language which were parallel to their field of study and interest from were encouraging for learners to improve their skills. As a conclusion for this part, Hitit.Moodle contributed to the motivation and autonomy of the learners to a certain extent.

\section{Conclusion}

In this study, Hitit.Moodle was used as an extension of the face-to-face language education. The students made use of on-line tools and activities provided over Hitit.Moodle for almost four months. When the term was over, the students filled a satisfaction questionnaire including eight questions on their level of motivation, frequency of using Hitit.Moodle, most challenging activities, etc. Exam results and statistics from the questionnaire by the students were compiled and evaluated in detail. From all the data it was concluded that Hitit.Moodle turned a promising tool as a motivator and autonomy builder in English language courses. The results from the questionnaire have particularly showed that there were several challenges both for the instructor of English and students, such as time management to build up content, management of the Hitit.Moodle system, technological infrastructures, access to Internet, the role of the instructor and grading system. All these challenges played an important part in feasibility of the Hitit.Moodle, as well.

All in all I believe that the research is of a value contributing to the Moodle applications as a new trend in the literature of English teaching as a foreign language. Many researchers emphasized the close link between success, motivation and autonomy. However, as far as I observed from my own research interest and willingness are also contributing to further motivation, the feeling of autonomous learning and psychology of achieving by the self, if we take success as only grades. I think these notions beginning with interests and willingness were just basic steps to autonomous and independent learning. In my study evidence from both exam results and questionnaire statistics suggested that Moodle applications might promote students motivation and autonomy to 
learn and improve English language on condition that the interests, needs and expectations of the teachers and students were truthfully defined and infrastructures of institution were put into service of all components of the university body. It was also concluded that any attempts to use Moodle-based projects may not easily be feasible without basic facilities from the institution.

\section{Acknowledgements}

I hereby declare that this paper is my unaided work and that I have given full acknowledgement in the content and in the bibliography to the resources I have used, and that this paper has not been submitted for any other degree or award. The names of the users of Hitit.Moodle and any contact details on the screen shots are intentionally anonymous and the samples from students' works and writings are chosen randomly, therefore nobody is of any responsibility to address any copyright or terms of use.

\section{References}

Borg, S., \& Al-Busaidi, S. (2011). Teachers’ Beliefs and Practices Regarding Learner Autonomy. ELT Journal, 66, $283-292$. http://dx.doi.org/10.1093/elt/ccr065

Chapelle, C. A. (2007). Autonomy Meets Individualization in CALL. TIC et autonomie dans l'apprentissage des langues (Mélanges CRAPEL, 28, 77-88). Nancy: CRAPEL. http://www.atilf.fr/IMG/pdf/melanges/5 CHAPELLE.pdf

Chateau, A., \& Zumbihl, H. (2012). Towards New Roles for Learners and Teachers in a Language Learning System? http://eurocall.webs.upv.es/documentos/newsletter/papers_20\%281\%29/08_chateau.pdf

Chourishi, D., Chanchal, K. B., Chaurasia, A., \& Soni, A. (2011). Effective E-Learning through Moodle. http://www.ijater.com/Files/IJATER_01_06.pdf

Dickinson, L. (1995). Autonomy and Motivation a Literature Review. System, 23, 165-174. http://www.sciencedirect.com/science/article/pii/0346251X95000055 http://dx.doi.org/10.1016/0346-251X(95)00005-5

Giesbers, B., Rienties, B., Tempelaar, D., \& Gijselaers, W. (2014). A Dynamic Analysis of the Interplay between Asynchronous and Synchronous Communication in Online Learning: The Impact of Motivation. Journal of Computer Assisted Learning, 30, 30-50. http://dx.doi.org/10.1111/jcal.12020

Gao, X., \& Lamb, T. (2011). Exploring Links between Identity, Motivation, and Autonomy. In G. Murray, X. Gao, \& T. Lamb (Eds.), Identity, Motivation and Autonomy in Language Learning. Clevedon: Multilingual Matters.

Gordon, D. T. (1975). Etkili Öğretmenlik Ĕgitimi (3rd Ed.). İstanbul: Profil Yayıncılık.

Hubackova, S., Semradova, I., \& Klimova, B. F. (2011). Blended Learning in a Foreign Language Teaching. Procedia-Social and Behavioral Sciences, 28, 281-285. http://dx.doi.org/10.1016/j.sbspro.2011.11.054

Jones, R. G. (2011). Emerging Technologies Autonomous Language Learning. Language Learning \& Technology, 15, 4-11. http://lit.msu.edu/issues/october2011/v15n3.pdf\#page=9

Mayer, R. E. (2013). Incorporating Motivation into Multimedia Learning. Learning and Instruction, 29, 171-173.

Moskovsky, C., Alrabai, F., Paolini, S., \& Ratcheva, S. (2013). The Effects of Teachers’ Motivational Strategies on Learners’ Motivation: A Controlled Investigation of Second Language Acquisition. Language Learning, 63, 34-62. http://dx.doi.org/10.1111/j.1467-9922.2012.00717.x

Peng, J.-E., \& Woodrow, L. (2010). Willingness to Communicate in English: A Model in the Chinese EFL Classroom Context. Language Learning, 60, 834-876. http://dx.doi.org/10.1111/j.1467-9922.2010.00576.x

Park, B., Plass, J. L., \& Brünken, R. (2013). Cognitive and Affective Processes in Multimedia Learning. Learning and Instruction, 29, 125-127.

Price, F., \& Kadi-Hanifi, K. (2011). E-Motivation! The Role of Popular Technology in Student Motivation and Retention. Research in Post-Compulsory Education, 16, 173-187. http://dx.doi.org/10.1080/13596748.2011.575278

Razak, R. A., \& See, Y. C. (2010). Improving Academic Achievement and Motivation through Online Peer Learning. Procedia-Social and Behavioral Sciences, 9, 358-362. http://dx.doi.org/10.1016/j.sbspro.2010.12.164

Staker, H., \& Horn, M. B. (2012). Classifying K-12 Blended Learning. Mountain View, CA: Innosight Institute. http://www.christenseninstitute.org/wp-content/uploads/2013/04/Classifying-K-12-blended-learning.pdf

Ushioda, E. (2011). Motivating Learners to Speak as Themselves. In G. Murray, X. Gao, \& T. Lamb (Eds.), Identity, Motivation and Autonomy in Language Learning. Clevedon: Multilingual Matters. 
Appendix 1

\begin{tabular}{|c|c|c|}
\hline \multicolumn{2}{|c|}{ Upper-Intermediate for CHEMISTRY IV } & $\begin{array}{l}\text { You are logged in as erdal ayan (Logour } \\
\text { English (en) }\end{array}$ \\
\hline \multicolumn{2}{|c|}{ Home $\bullet$ Courses English Courses $\$ CHEM IV UPPER-INT. } & Turn editing on \\
\hline \multirow{10}{*}{ 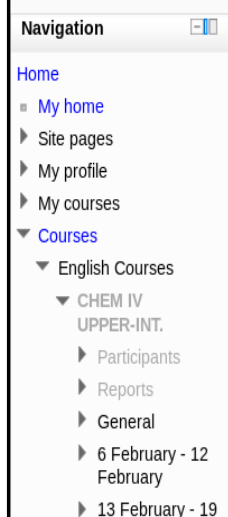 } & \multirow{3}{*}{ 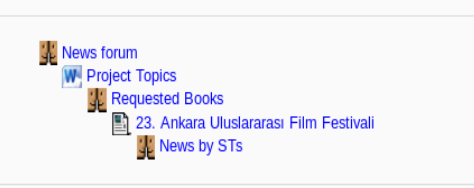 } & Search forums \\
\hline & & $\frac{\text { Go }}{\text { Advanced search (3) }}$ \\
\hline & & Latest news \\
\hline & \multirow{4}{*}{$\begin{array}{l}6 \text { February - } 12 \text { February } \\
\text { 骂 Solar Energy from the Desert } \\
\text { 4) A Serious Case } \\
\text { A S Serious Case } \\
\text { — Weekly Writing }\end{array}$} & \multirow{2}{*}{$\begin{array}{l}\text { Add a new topic... } \\
\text { (No news has been posted } \\
\text { yet) }\end{array}$} \\
\hline & & \\
\hline & & \multirow{4}{*}{$\begin{array}{l}\text { Upcoming events } \\
\text { There are no upcoming } \\
\text { events } \\
\text { Go to calendar... } \\
\text { New event... }\end{array}$} \\
\hline & & \\
\hline & 13 February - 19 February & \\
\hline & $\begin{array}{l}\text { 煰 Let it Snow } \\
\text { Archeology } \\
\text { Cob Mobile Phones }\end{array}$ & \\
\hline & 口 Weekly Writing Topic 2 & YöK (IDE) PORTAL FII] \\
\hline $\begin{array}{l}20 \text { February - } 26 \\
\text { February }\end{array}$ & \multirow{4}{*}{ 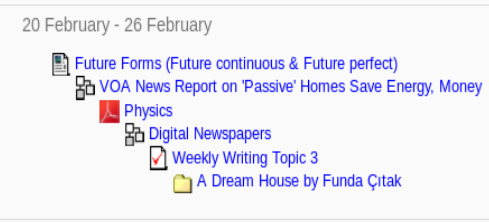 } & 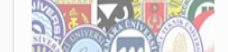 \\
\hline $\begin{array}{l}27 \text { February - } 4 \\
\text { March }\end{array}$ & & \\
\hline $\begin{array}{l}5 \text { March - } 11 \\
\text { March }\end{array}$ & & 12 \\
\hline $\begin{array}{l}12 \text { March - } 18 \\
\text { March }\end{array}$ & & \\
\hline - 19 March - 25 & \multirow{2}{*}{$\begin{array}{l}27 \text { February - } 4 \text { March } \\
\mathbb{\Delta}_{\text {A Zulu Dictionary }} \\
\text { 嗎 Energy }\end{array}$} & \multirow{2}{*}{$\begin{array}{l}\text { Recent activity } \\
\text { Activity since Friday, 12 July } \\
2013,11: 13 \text { PM } \\
\text { Full report of recent activity... }\end{array}$} \\
\hline $\begin{array}{l}\text { March } \\
\text { - } 26 \text { March-1 April }\end{array}$ & & \\
\hline
\end{tabular}

Screen Shot 1. Screen shot of course content for upper-intermediate students.

BBC Documentary
Archive
Docs: Race for Equality,
Episode 1, 16 July 2013
Tatyana McFadden is one of the most
successful wheelchair racers in
Paralympic history - but it's her
victories off the track that have defined
her.
Docs: Law Behind Bars 14 July
2013
Meet the Kenyan prisoners acting as
lawyers on behalf of themselves and
fellow inmates. Most people who face
criminal charges in Kenya go to court
without a lawyer. By the Kenyan
judiciary's own admission, this leads to
a great deal of injustice.
Docs: Greece - In Sickness and
in Debt 11 July 2013
Zeinab Badawi talks to doctors and
patients who struggle to cope as
hospitals in Greece are hit by cuts and
are running out of basic medical
supplies.
$\quad$ Source site...
Dow

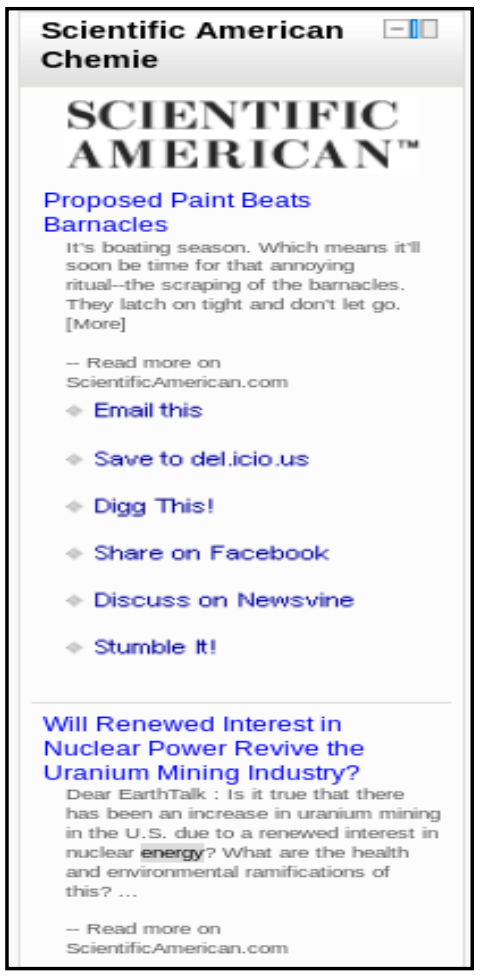

\section{BBC Documentary $-0 \square$ Archive

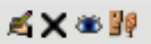

Docs: Race for Equality, Episode 1, 16 July 2013

Tatyana McFadden is one of the most successful wheelchair racers in Paralympic history - but it's her victories off the track that have defined her.

Docs: Law Behind Bars 14 July 2013

Meet the Keryan prisoners acting as lawyers on behalf of themselves and fellow inmates. Most people who face criminal charges in Kernya go to court without a lamyer. By the Kernyan judiciary's own admission, this leads to a great deal of injustice.

Docs: Greece - In Sickness and in Debt 11 July 2013

Zeinab Badawi talks to doctors and patients who struggle to cope as hospitals in Greece are hit by cuts and are running out of basic medical supplies.

Source site...

Screen Shot 2. Rss feeds from different sources. 


\title{
Appendix 2
}

\author{
Questionnaire on Hitit.Moodle
}

This questionnaire was prepared by Erdal Ayan, instructor of English. It just aims to find out attitudes/experience and the level of motivation and autonomy of the chemistry students towards Hitit.Moodle which was founded in February, 2012. The results and implications of the questionnaire are going to be used for educational and academic purposes.

Question 1-How often did you login to Hitit.Moodle in a week?
a) once a week
b) twice a week
c) three times a week or more
d) never

Question 2-How often did you find it difficult to find your way around Hitit.Moodle?
a) always
b) frequently c) sometimes
d) never

Question 3-Did Hitit.Moodle help you learn new things?

a) It helps a lot. b) It does not help.

Question 4-Did Hitit.Moodle help you revise things you learned in lectures?
a) Yes
b) No

Question 5-What were main activities/practices that you found influential in improving your English knowledge?
a) forums b) listening activities
c) grammar packages
d) informative web-links

e) short videos

f) Weekly essay writing

g)

Question 6-In less than 4 sentences, explain what you liked and didn't like about Hitit.Moodle.

Like:

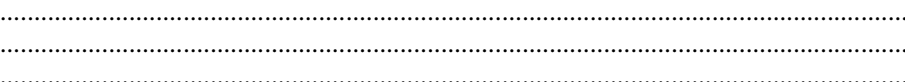

Dislike:

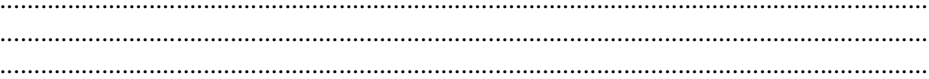

Question 7-How often did the instructor provide you enough help/guidance to learn how to use Hitit.Moodle?
a) always b) frequently c) sometimes
d) never

Question 8-Would you think that you can use Hitit.Moodle in your future studies or for your own students?

$\begin{array}{ll}\text { a) Yes } & \text { b) No }\end{array}$

\section{Appendix 3}

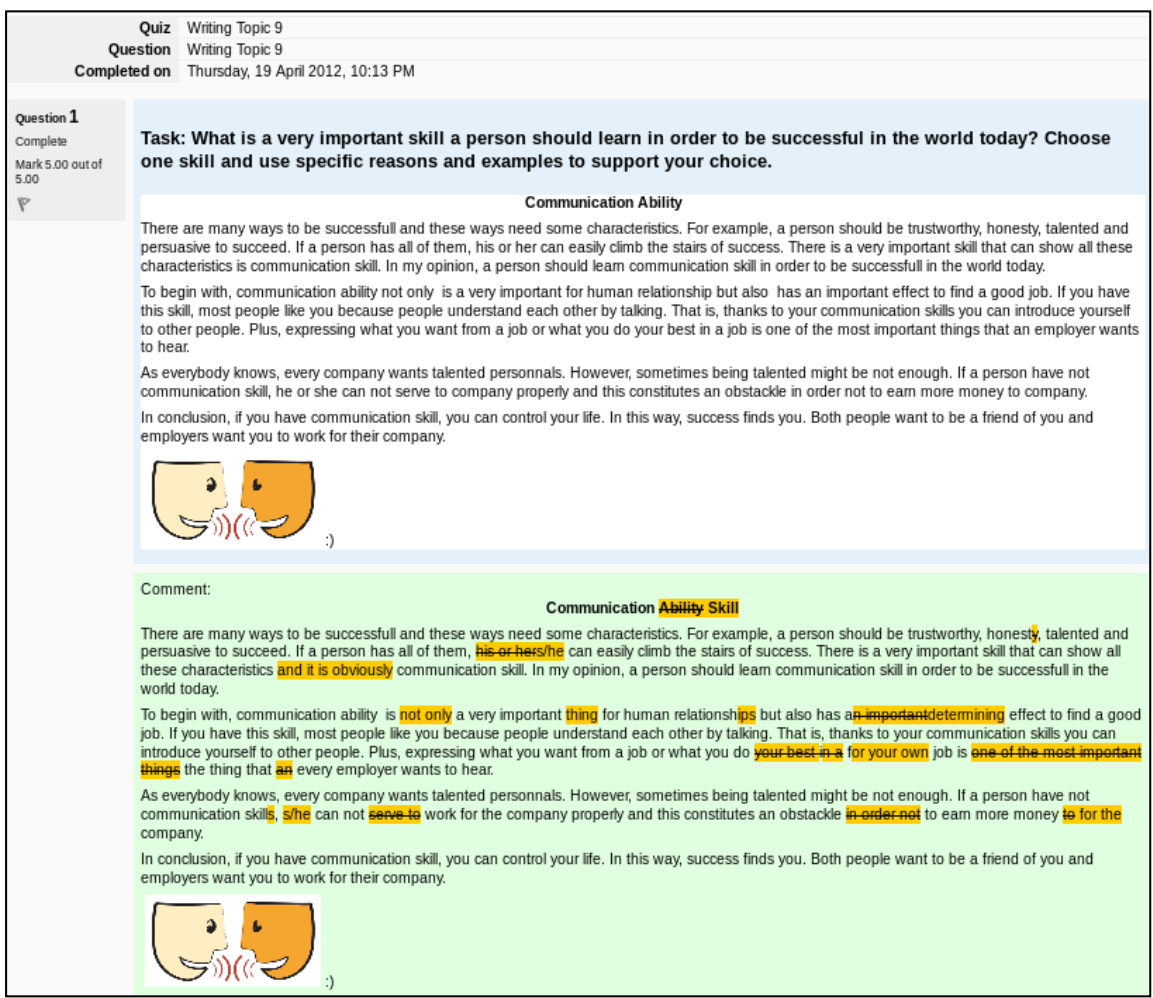

Screen Shot 3. Writing assignment. 


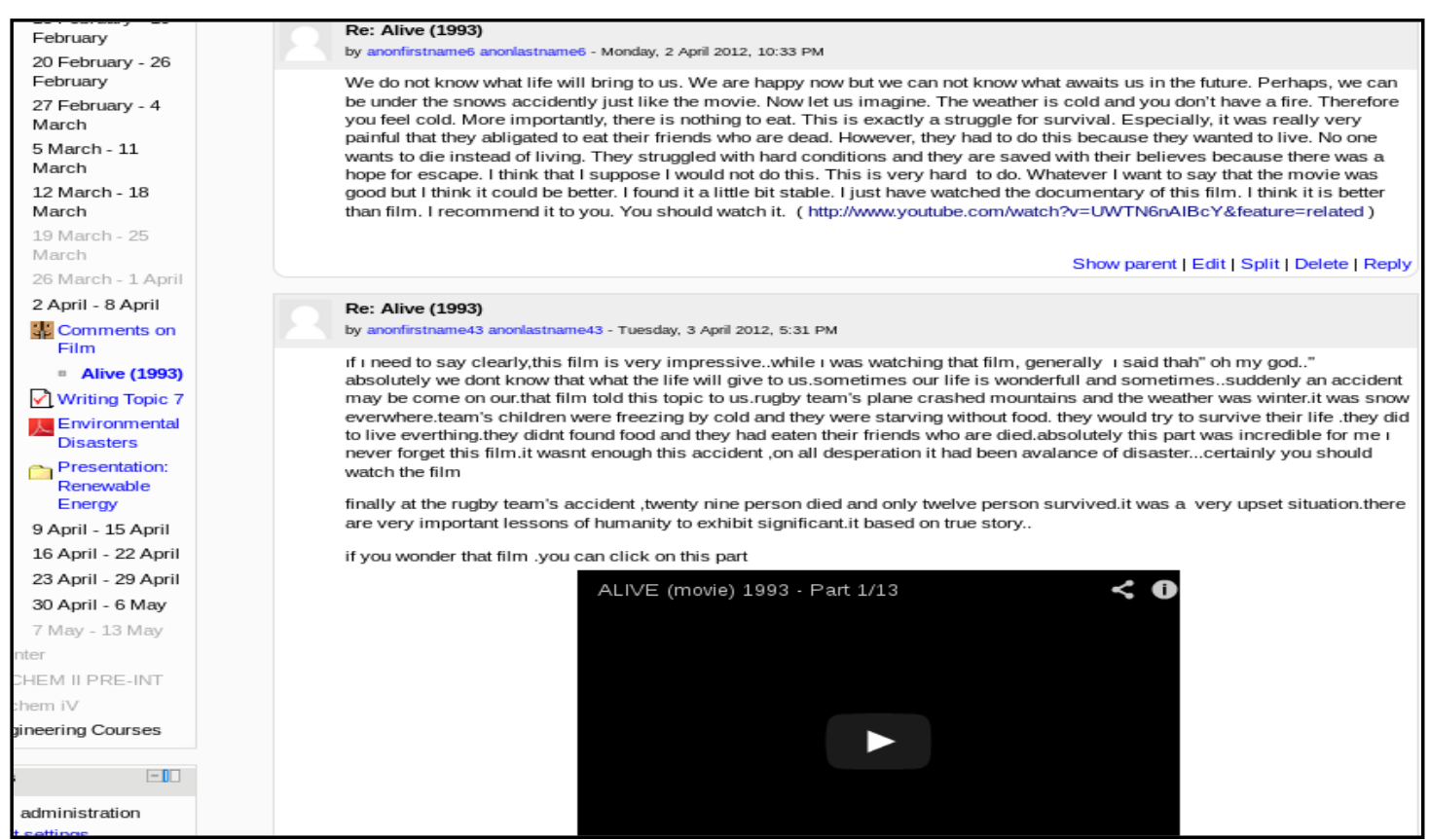

Screen Shot 4. Forum discussion.

\section{Appendix 4}

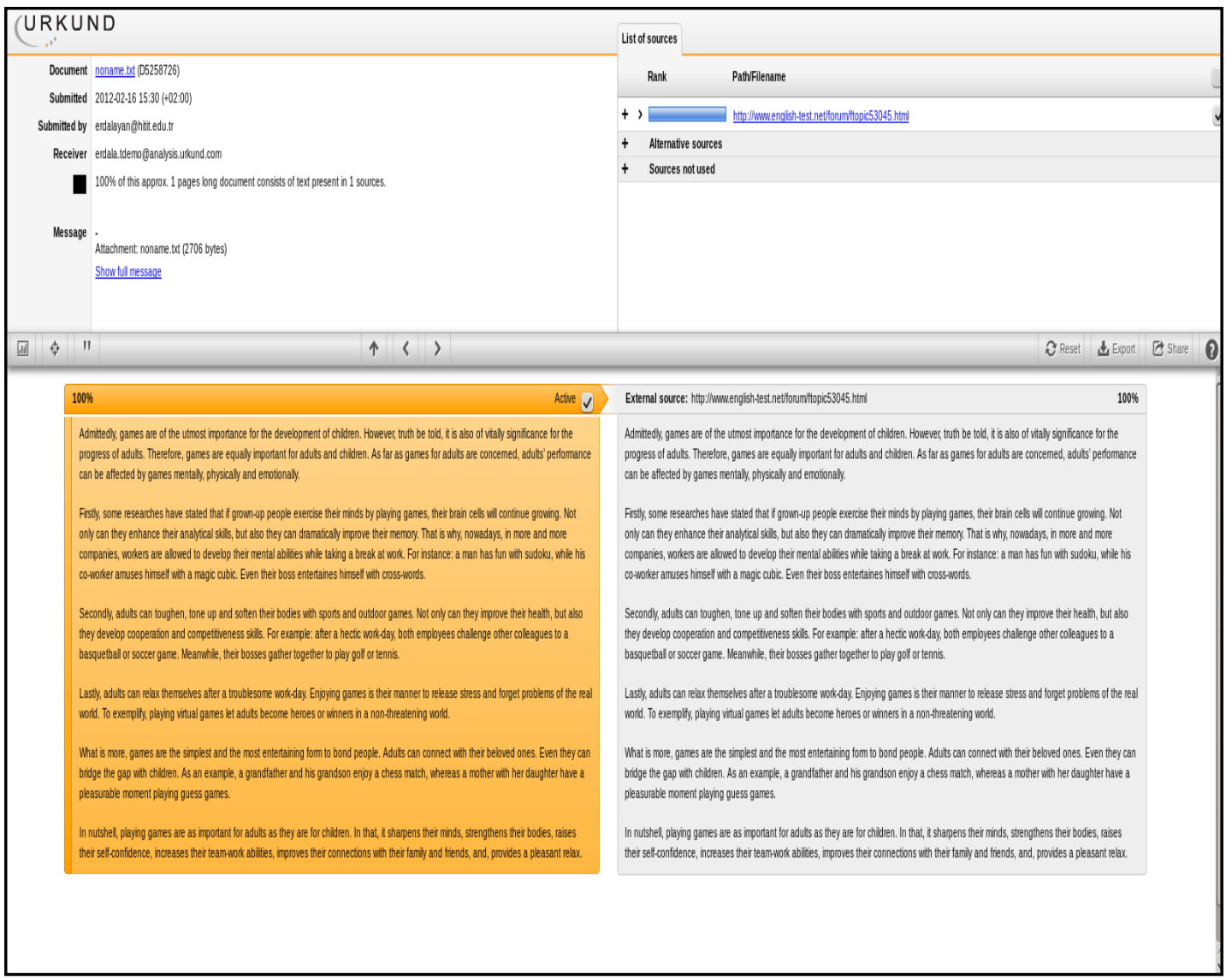

Screen Shot 5. A plagiarized text by a student. 
Scientific Research Publishing (SCIRP) is one of the largest Open Access journal publishers. It is currently publishing more than 200 open access, online, peer-reviewed journals covering a wide range of academic disciplines. SCIRP serves the worldwide academic communities and contributes to the progress and application of science with its publication.

Other selected journals from SCIRP are listed as below. Submit your manuscript to us via either submit@scirp.org or Online Submission Portal.
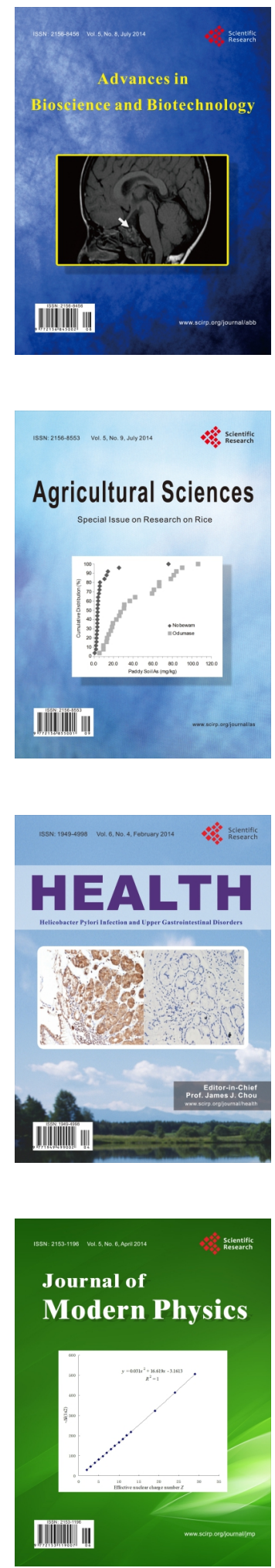
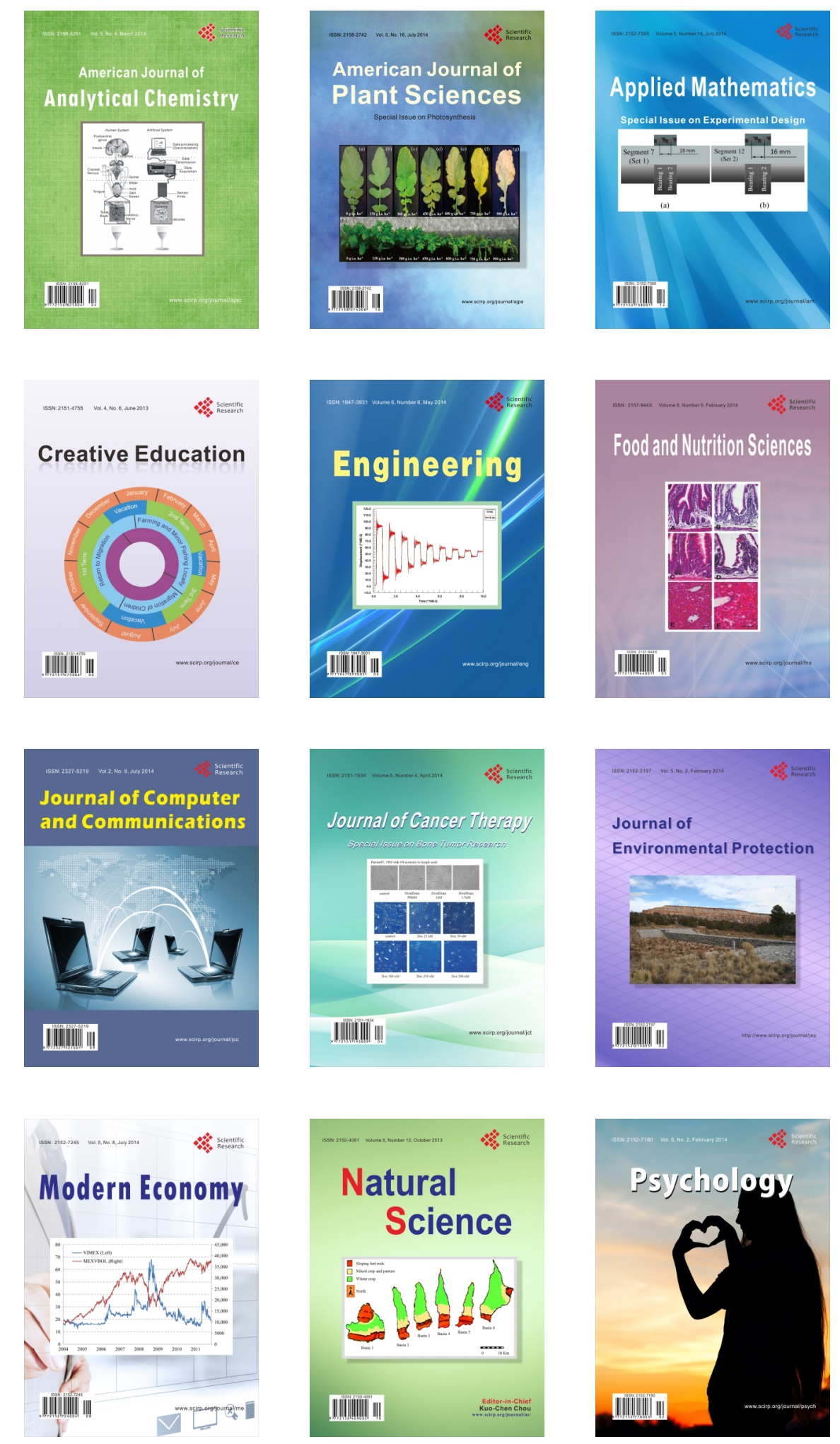